\title{
Financial Analysis and Business Feasibility Study of Cinnamon Jelly Candy
}

\author{
Setiarti Sukotjo \\ Dept. of Agro-Industrial Technology Institut Teknologi Indonesia \\ Tangerang Selatan, Indonesia \\ teti.sukotjo@iti.ac.id \\ Muhami \\ Dept. of Agro-Industrial Technology Institut Teknologi Indonesia \\ Tangerang Selatan, Indonesia \\ muhami@iti.ac.id
}

\author{
Indrati Sukmadi \\ Dept. of Informatics Institut Teknologi Indonesia \\ Tangerang Selatan, Indonesia \\ indrati.sukmadi@iti.ac.id \\ Alifatul Mastikha \\ Dept. of Agro-Industrial Technology Institut Teknologi Indonesia \\ Tangerang Selatan, Indonesia \\ amastikha@gmail.com
}

\begin{abstract}
The Government of Indonesia is targeting the performance of small and medium-sized industries (IKM) to grow above 10 percent in 2018. One of food products that can be developed in a small-scale industry is seaweed-based jelly candy with cinnamon flavor. The aim of the research is to understand the financial analysis and business feasibility of establishing a small-scale industry of cinnamon jelly candy, as well as developing a production plant layout for the jelly candy industry. The methodology consists of several steps, setting the location and presumptions, analyzing Net Present Value, BenefitCost Ratio, Internal Rate of Return, Pay Back Period and, designing the layout of the production area. The result shows that production of candy jelly in one production batch is 334 packs and the price is $R$ p. 9,300 per package. The discount factor is $\mathbf{9 . 7 5 \%}$ for a five-year projection. With the Net Present Value is Rp. 47,256,870, the BenefitCost Ratio is 1.09, the Internal Rate of Return is $32.82 \%$, and the Pay Back Period is 2 years 3 months and 21 days. Layout of the production area was adjusted based on the order of the production process using the Activity Relationship Chart method. It is possible to develop small-scale industry of cinnamon jelly candy with $19 \%$ profit of the production price. Thus, this will support the growth of small industries in Indonesia.
\end{abstract}

Keywords-business feasibility, financial analysis, industrial layout, jelly candy, seaweed

\section{INTRODUCTION}

The use of seaweed Eucheuma cottonii for processed food products in Indonesia is still relatively low. Therefore, business opportunities to develop the seaweed-based food industry are still wide open. Further business development research is needed in processing seaweed into various food products. One of the processed food products that can be developed is seaweed-based jelly candy.

Banten province is an area that has great opportunities for the use of processed seaweed products, because the area is close to the sea. It can increase the economic value of the seaweed and provide business opportunities for the surrounding community. Unfortunately, currently there are no food products derived from seaweed in Banten.
Jelly candies are candies made from water or fruit juice and gel-forming ingredients that look clear, transparent and have a texture with a certain elasticity. The gelling ingredients that can be used are gelatin, carrageenan and agar or a combination of these ingredients [1]. Jelly Candy is classified as a semi-wet food processed product, and therefore, this product is easily damaged if not properly packaged.

Previous research uses variety of fruits flavors and a mixture of hydrocolloid substances such as carrageenan, alginate, agar, gelatin, gum and many others [2,3]. This research is different from previous researches since hydrocolloid substance was not extracted from the seaweed, but the whole seaweed is used to produce the jelly candy. As for flavor, cinnamon was chosen because of its unique taste, availability and varieties of bioactive components. Another benefit of this seaweed-based cinnamon jelly candy is that it has a high dietary fiber content.

Many developing countries encourage the growth of small-scale industries since they play a very important role in the economy [4]. Providing a business development for seaweed-based cinnamon jelly candy can be a great opportunity for people who want to start enterprises, because only a few have established a business model, both small and large scale industries. Ninety-nine percent of business entities in Indonesia are Small and Medium Enterprises (SMEs) that contribute largely to the Indonesian economy, which is especially felt during times of economic crises. Recently, the Government of Indonesia has greatly increased efforts to develop small and medium-sized industries.

The cinnamon jelly candy business is a relatively new kind of business, that has not been well developed in Banten Province, Indonesia. Therefore, the jelly candy business has a great opportunity to develop and contribute to the growth of Banten's small scale industry. To find out whether or not this business is feasible, financial analysis is required.

The aims of this research are to determine the financial feasibility of establishing a small-scale seaweed-based cinnamon-flavored jelly candy business and to design and determine the layout of the production area. 


\section{METHODS}

The research was conducted from October 2017 to March 2018 at Institut Teknologi Indonesia and was carried out in two stages. The first stage was direct observation of the production process, production time and cycle, the determination of the equipment used and production costs at laboratory scale. The second stage consisted of determining the production process, production cycle time, the area required for equipment in a small-scale industry, measurement of space layout, calculation of costs and analysis of business feasibility.

The production process for cinnamon jelly candy can be seen in Figure 1.

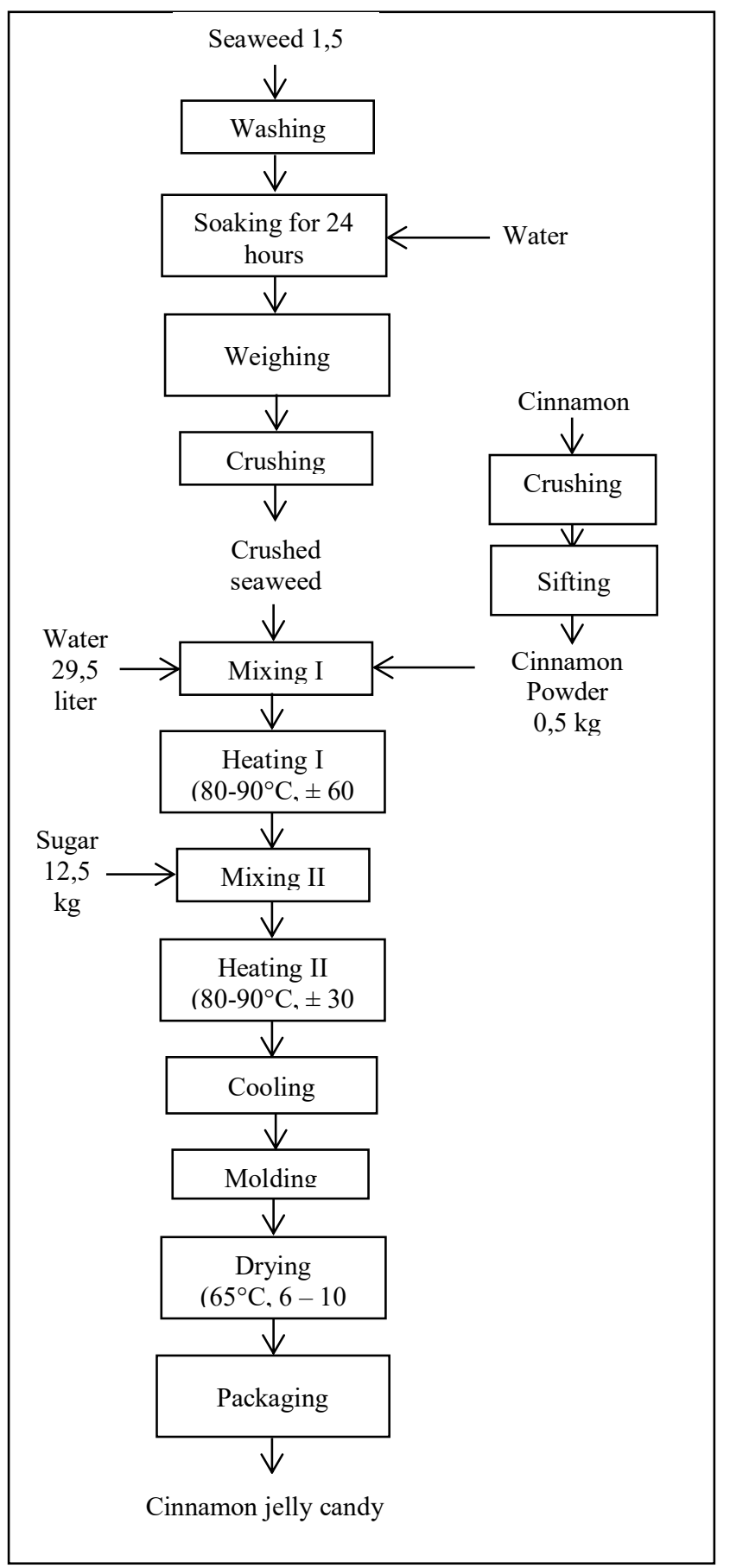

Figure 1.The flowchart of cinnamon jelly candy production process
This study examines the production process and cycle, as well as the amount of raw materials used and also determines the equipment used and needed for a small industry. It also determines the best area to obtain the main raw materials for small-scale industries. The seaweed is obtained from the Lontar Village community in Tirtayasa, Serang, Banten, which cultivates $E$. cottonii seaweed.

Assumptions must be made before the financial analysis and feasibility study is conducted. The assumptions are that one cycle of production is $50 \mathrm{~kg}$ of total raw material; an industrial economic period of five years; prices are assumed to be stable during the assessment period, which was the end of 2017 and early 2018; production capacity during the study period is $100 \%$; discount factor is set at $9.75 \%$ based on BRI's retail interest rate in 2017; and, the capital used is personal.

In this research, cinnamon jelly candy industry is assumed to be located in an industrial area in Pandeglang, Banten. Layout design is conducted based on the number of process activities and, the flow of the production process, so that the area needed for each activity is based on existing capacity and knowledge of a good layout to run a small industry of cinnamon-flavored jelly candy.

The financial analysis calculates the costs needed to run the cinnamon jelly candy industry, based on the assumptions mentioned above. The industrial feasibility used in this research includes indicators such as Net Present Value (NPV), Benefit Cost Ratio (B / C Ratio), Internal Rate of Return (IRR), Pay Back Period (PBP) and Break Even Point (BEP) and determination of discount factors by using calculations which include NPV, B/C Ratio, IRR, PBP and BEP.

Sensitivity analysis is doneby increasing production costs by $4 \%$ per year and decreasing the production amount by $4 \%$ per year. The percentage used above the average inflation rate for October 2017 to March 2018 is 3.39\% [5].

ARC is a simple technique in planning facility layout based on activity relationships that are often stated in "qualitative" assessments and tend to be based on subjective considerations of each facility [6]. To describe the interrelationships between work activities ARC charts are used which are given the degree of work relations expressed by the symbols A, E, I, O, U and X which means:

A (Absolute), which indicates that the location between activities must be adjacent and adjacent.

$\mathrm{E}$ (Especially important), which indicates that the location between activities must be close together.

I (Important), which indicates that the location between activities is close enough.

O (Ordinary), which indicates that the location between activities does not have to be close together.

$\mathrm{U}$ (Unimportant), which shows that the location between activities is free and not bound together.

$\mathrm{X}$ (Undesirable), which indicates that the location between activities should not be close together

The ARC chart can function to determine the location of the work center in an industry, determine the location of the facility in the area of production, show work activities that are interrelated, as a basis for determining the location of the activity area in an industry. 


\section{RESULTS AND DISCUSSION}

One production cycle with an entire capacity of $50 \mathrm{~kg}$ used $1.5 \mathrm{~kg}$ of dry seaweed, $12.5 \mathrm{~kg}$ of sugar, $0.5 \mathrm{~kg}$ of cinnamon, and 29.5 liters of water. The main raw material for making the jelly candy is dried seaweed E. cottonii that has been bleached and obtained from Lontar Village, one of the areas located in Banten that cultivates seaweed and is not far from the factory location.

Fifty $\mathrm{kg}$ of total raw material will produce $16.71 \mathrm{~kg}$ of jelly candy. From $16.71 \mathrm{~kg}$, production of cinnamon jelly candy at small scale industry can produce 334 packages per day or 5,344 packages in one month. It takes two days to complete one cycle of cinnamon jelly candy production.

In establishing a small scale industry of seaweed-based cinnamon jelly candy, business development costs are divided into two parts, namely fixed costs and non-fixed costs. Fixed costs in the cinnamon jelly candy industry are the energy costs incurred by the industry. The fixed cost per year is Rp. 291,697,699, which includes labor cost (including the holiday allowance obtained by each employee once a year). The salary for each employee is different, according to workload, total work hours and job positions in the industry. Employees from production unit have less working hours compare to other employees on Friday. This is because the production process does not take place on Friday. Therefore, those employees work for half a day on product packaging.

In one week there are five working days, or 20 working days in a month, or 240 working days in one year. The candy drying process is carried out for up to ten hours, so that the candy packaging is done the following day after the drying process.

As for non-fixed costs in the jelly candy industry, these include raw material costs, packaging costs, and fuel costs incurred by the industry. Non-fixed costs per year in the jelly candy industry is Rp. 273,043,696. The packaging costs include the cost of transparent plastic packaging bottles and the packaging label needed for one year. Fuel costs consist of electricity and water costs, gas, motor fuel, vehicle service, and telephone costs required by the industry for one year.

The investment capital needed to build a cinnamon jelly candy industry is Rp. 72,576,700 which includes leasing of land, tools and equipment costs as well as office equipment costs. In this small industry, the land is rented for a predetermined period of time. At the beginning of this business, the space was leased in an industrial estate rather than directly building a permanent plant in order to minimize the risk.

The results of the financial analysis is presented in Table 1. A sensitivity analysis was conducted to find out whether the small industrial business of cinnamon jelly candy was still feasible to run if it experienced certain economic changes.

The assumption used in the analysis is a $4 \%$ increase in production costs and a $4 \%$ decrease in net production. From the results of the analysis carried out, the NPV value obtained for the increase in production costs and the decrease in the amount of production is positive.
Table 1. Results of financial analysis and sensitivity analysis

\begin{tabular}{|c|c|c|c|}
\hline \multirow[b]{2}{*}{$\begin{array}{c}\text { Business } \\
\text { Feasibility } \\
\text { Criteria }\end{array}$} & \multicolumn{2}{|c|}{ Sensitivity Analysis } & \multirow[b]{2}{*}{$\begin{array}{c}\text { Financial } \\
\text { Analysis }\end{array}$} \\
\hline & $\begin{array}{c}\text { Productio } \\
\text { n Cost } \\
+4 \%\end{array}$ & $\begin{array}{c}\text { Net } \\
\text { Productio } \\
\text { n }-4 \%\end{array}$ & \\
\hline Periode & 5 years & 5 years & 5 years \\
\hline Investment & $\begin{array}{cc}\mathrm{R} & 72.576 \\
\mathrm{p} & .700\end{array}$ & $\begin{array}{cc}\mathrm{R} & 72.576 \\
\mathrm{p} & .700\end{array}$ & $\begin{array}{ll}\text { R } & 72.57 \\
\text { p. } & 6.700\end{array}$ \\
\hline $\begin{array}{l}\text { Non-fixed cost } \\
\text { (per year) }\end{array}$ & $\begin{array}{cc}\mathrm{R} & 283.37 \\
\mathrm{p} & 2.169 \\
\end{array}$ & $\begin{array}{cc}\mathrm{R} & 262.71 \\
\mathrm{p} & 5.224\end{array}$ & $\begin{array}{r}273.0 \\
43.69 \\
6 \\
\end{array}$ \\
\hline $\begin{array}{l}\text { Fixed cost } \\
\text { (per year) }\end{array}$ & $\begin{array}{cc}\mathrm{R} & 291.69 \\
\mathrm{p} & 7.699 \\
. & \end{array}$ & $\begin{array}{cc}\mathrm{R} & 289.31 \\
\mathrm{p} & 2.138 \\
. & \end{array}$ & $\begin{array}{r}291.6 \\
97.69 \\
9\end{array}$ \\
\hline Total cost & $\begin{array}{cc}\mathrm{R} & 575.06 \\
\mathrm{p} & 9.868 \\
. & \\
\end{array}$ & $\begin{array}{cc}\mathrm{R} & 552.02 \\
\mathrm{p} & 7.361 \\
. & \\
\end{array}$ & $\begin{array}{r}564.7 \\
41.39 \\
5\end{array}$ \\
\hline $\begin{array}{l}\text { Total } \\
\text { Production/ye } \\
\text { ar }\end{array}$ & $\begin{array}{c}64.128 \\
\text { packages }\end{array}$ & $\begin{array}{c}\text { 61.563pac } \\
\text { kages }\end{array}$ & $\begin{array}{r}64.128 \\
\text { packages }\end{array}$ \\
\hline $\begin{array}{l}\text { Price (per } \\
\text { package) }\end{array}$ & 9.300 & 9.300 & $\begin{array}{l}\mathrm{R} \\
\mathrm{p} .\end{array}$ \\
\hline Revenue & $\begin{array}{cc}\mathrm{R} & 596.39 \\
\mathrm{p} & 0.400 \\
. & \\
\end{array}$ & $\begin{array}{cc}\mathrm{R} & \\
\mathrm{p} & 572.53 \\
& 4.784\end{array}$ & $\begin{array}{r}596.3 \\
90.40 \\
0 \\
\end{array}$ \\
\hline Benefits & $\begin{array}{cc}\mathrm{R} & 21.320 \\
\mathrm{p} & .532 \\
. & \end{array}$ & $\begin{array}{cc}\mathrm{R} & 20.507 \\
\mathrm{p} & .423 \\
. & \end{array}$ & $\begin{array}{l}31.64 \\
9.005\end{array}$ \\
\hline $\begin{array}{l}\text { Discount } \\
\text { Factor }\end{array}$ & $9,75 \%$ & $9,75 \%$ & $9,75 \%$ \\
\hline $\begin{array}{l}\text { Net Present } \\
\text { Value (NPV) }\end{array}$ & $\begin{array}{c}7.852 . \\
488\end{array}$ & $\begin{array}{c}4.750 . \\
377\end{array}$ & $\begin{array}{l}47.25 \\
6.870\end{array}$ \\
\hline $\begin{array}{l}\text { Net Benefit } \\
\text { Cost Ratio } \\
\text { (B/C Ratio) }\end{array}$ & $\begin{array}{l}1,07> \\
1\end{array}$ & $\begin{array}{l}1,07> \\
1\end{array}$ & $\begin{array}{l}1,09> \\
1\end{array}$ \\
\hline $\begin{array}{l}\text { Internal Rate } \\
\text { of Return } \\
\text { (IRR) }\end{array}$ & $\begin{array}{l}13,89 \\
\%\end{array}$ & $\begin{array}{l}12,27 \\
\%\end{array}$ & $\begin{array}{l}32,82 \\
\%\end{array}$ \\
\hline $\begin{array}{l}\text { Payback } \\
\text { Period (PBP) }\end{array}$ & $\begin{array}{c}\text { 3years } \\
\text { 5months } 12 \\
\text { days } \\
\end{array}$ & $\begin{array}{c}\text { 3years } \\
7 \text { months } 2 \\
\text { days } \\
\end{array}$ & $\begin{array}{c}2 \text { years } \\
\text { 3months } 21 \\
\text { days } \\
\end{array}$ \\
\hline $\begin{array}{l}\text { Break Event } \\
\text { Point (BEP) }\end{array}$ & $\begin{array}{c}55.423 \\
\text { packages }\end{array}$ & $\begin{array}{c}53.201 \\
\text { packages }\end{array}$ & $\begin{array}{c}54.312 \\
\text { packages }\end{array}$ \\
\hline
\end{tabular}

The B / C Ratio obtained for the assumption of the analysis carried out is more than one. The IRR value obtained for the $4 \%$ production cost increase is $13.89 \%$ and for the $4 \%$ production decrease is $12.27 \%$. The IRR value obtained in both assumptions is greater than the discount factor, which is $9.75 \%$. According to the results of the sensitivity analysis carried out on the calculation of NPV, IRR and B / C Ratio, this small cinnamon jelly candy industry business is feasible to run even if it has increased production costs of $4 \%$ and a decrease in production of $4 \%$. Thus, the results showed that it is a good prospect to develop a jelly candy business in Indonesia. 
The PBP values obtained based on the assumption of an analysis of a $4 \%$ increase in production costs is 3 years 5 months 12 days, and for a decrease in production amount of $4 \%$ is 3 years 7 months 2 days. From the results obtained, it can be concluded that the PBP value is more sensitive to the decrease in the amount of production than the increase in production costs.

Other research on the feasibility study of jelly candy made from sugar palm fruit was reported by [7]. Despite the differences in assumption and location, in general, the results of this study are in accordance with the research conducted by [6]. Furthermore, other research that calculated the business feasibility rainbow jelly candy also showed profitable results, so that business can be implemented [8].

Activity Relationship Chart (ARC) technique is one of the methods used to design the plan layout [9]. ARC is also known as REL chart which is used to show the significance of adjacency between each pair of activities [10]. Basically, it is a simple technique for designing a planning facility. The linkages between work activities are used to analyze the interrelationships between activities.

In the relationship chart between work activities, there is a letter that symbolizes the degree of interrelation between activities, while the number symbolizes the interrelation between activities that gives the reason for the cause of an activity related to other activities. The linkages between work activities in the jelly candy business is presented in Figure 2.

Generally, there are six closeness rating values (A, E, I, $\mathrm{O}, \mathrm{U}$, and $\mathrm{X}$ ) in an ARC which may be given to each pair of activities [11]. The chart in Figure 2 translates the vowelletter rating valueon the relationship chart to a desired closeness graphic visualization among activity-rooms or areas. The activities of cinnamon jelly candy production are divided into 13 activities. The activities were listed according to the steps of material flow in the processing and according to the additional activities in the industry such as administration, resting, and praying.

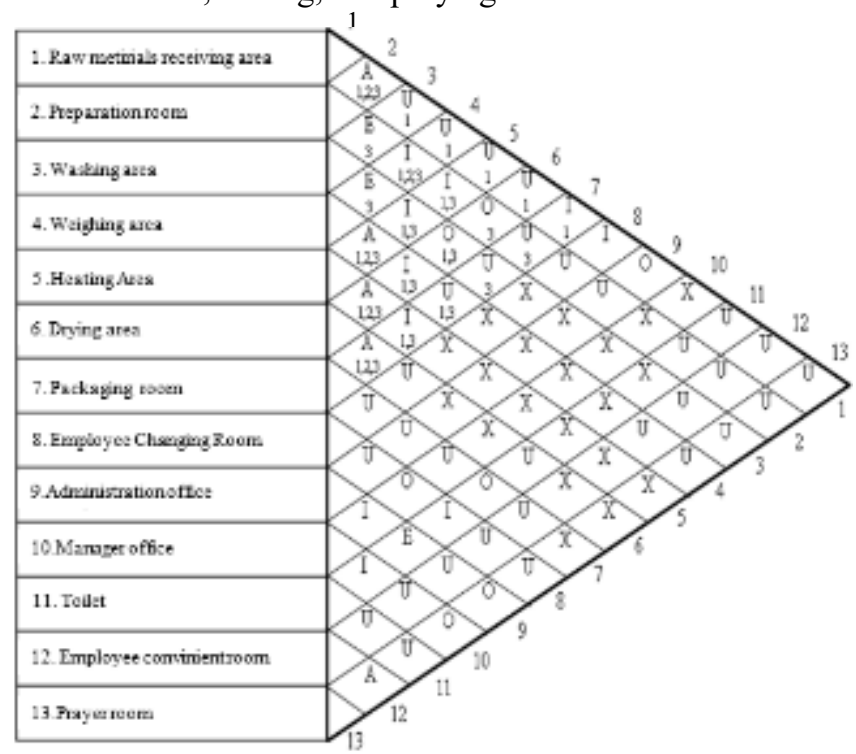

Figure2. ACR chart

The numbers that exist in several cells on the chart symbolize the reason the activity is related to other activities. Information generated from the chart working relationship can be used in making the layout design of the space. The layout is also based on the needs of tools and equipments that need to be fitted in each room.

Table 2.Room and area sizes of the cinnamon jelly candy industrial plant

\begin{tabular}{|c|c|c|}
\hline $\begin{array}{c}\text { Room /Area } \\
\text { No. }\end{array}$ & Activity & Size \\
\hline 1 & Raw metirials receiving area & $4 \mathrm{~m} \times 3 \mathrm{~m}$ \\
\hline 2 & Preparation room & $4 \mathrm{~m} \mathrm{x} 4 \mathrm{~m}$ \\
\hline 3 & Washing area & $4 \mathrm{~m} \times 3 \mathrm{~m}$ \\
\hline 4 & Weighing area & $4 \mathrm{~m} \times 3 \mathrm{~m}$ \\
\hline 5 & Heating area & $3 \mathrm{~m} \times 3 \mathrm{~m}$ \\
\hline 6 & Drying area & $4 \mathrm{~m} \times 3 \mathrm{~m}$ \\
\hline 7 & Packaging room & $4 \mathrm{~m} \times 4 \mathrm{~m}$ \\
\hline 8 & Employee Changing Room & $4 \mathrm{~m} \times 3 \mathrm{~m}$ \\
\hline 9 & Administration Office & $4 \mathrm{~m} \times 3 \mathrm{~m}$ \\
\hline 10 & Manager office & $4 \mathrm{~m} \times 3 \mathrm{~m}$ \\
\hline 11 & Toilet & $3 \mathrm{~m} \times 2 \mathrm{~m}$ \\
\hline 12 & Employee convinient room & $3 \mathrm{~m} \times 2 \mathrm{~m}$ \\
\hline \multirow[t]{4}{*}{13} & Prayer room & $4 \mathrm{~m} \times 2 \mathrm{~m}$ \\
\hline & Building Length & $13 \mathrm{~m}$ \\
\hline & Building Width & $12 \mathrm{~m}$ \\
\hline & Building area & $156 \mathrm{~m}^{2}$ \\
\hline
\end{tabular}

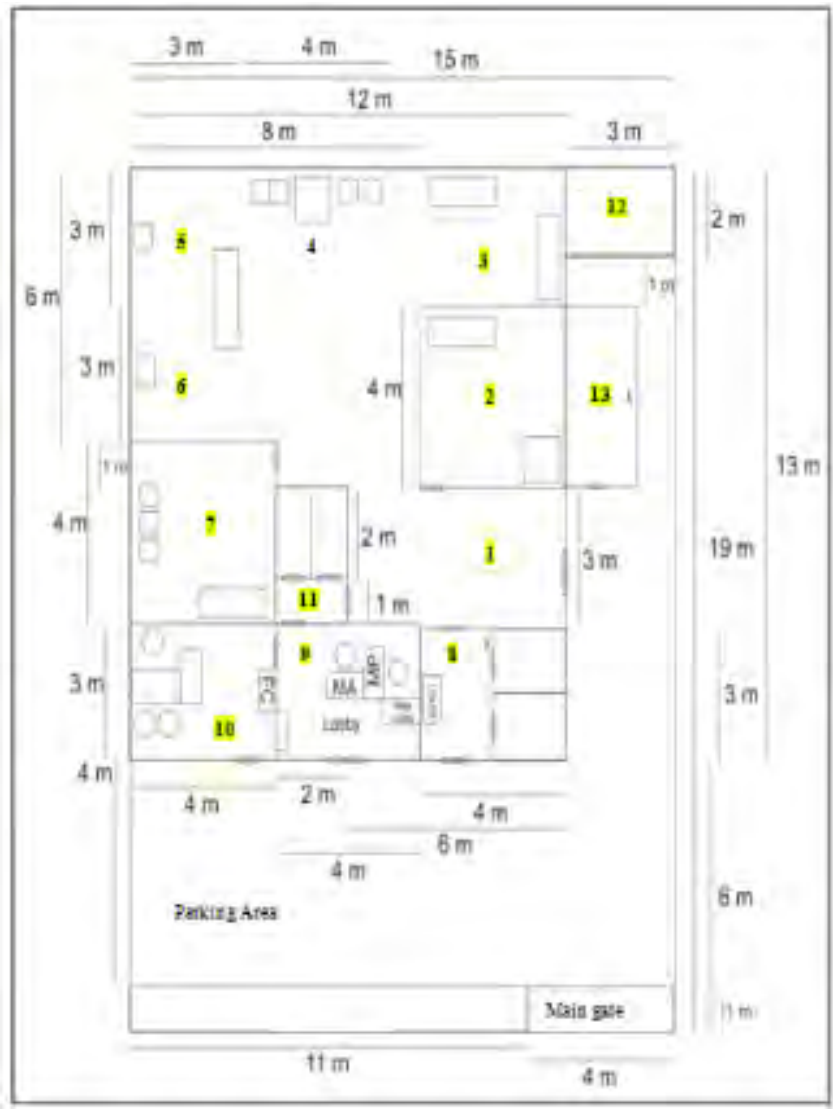

Figure3.Layout design of a cinnamon jelly candy industry

The layout and industrial space design of cinnamon jelly candy is divided into 13 rooms/areas, according to the activitymentioned in the ARC chart. Room and area sizes of 
cinnamon jelly candy'sindustrial plant are shown in Table 2 . The size of each room is related not only to the activities but also to the size of equipments and tools placed in the room. Most of the rooms have a $4 \mathrm{~m} \mathrm{x} 3 \mathrm{~m}$ size. The total building area is $156 \mathrm{~m}^{2}$ with the size of $13 \mathrm{~m} \times 12 \mathrm{~m}$.

Figure 3 shows that the area of industrial building space is $156 \mathrm{~m} 2$; this is adjusted to the existing space requirements. The total land area of the industry is $285 \mathrm{~m}^{2}$. This total land area includes a place to park vehicles and for the in and out flow of the vehicles for the distribution of products or the purchase of raw materials if using two or more wheeled vehicles.

The main gate is in front and at the right hand-side so that it will give straight access to the plant for incoming raw materials. As for the guest enterance, the lobby and main administration offices, they are in the front area of the building, and thus is easy to find. The flow of process starts from the right side of the building. It begins with area one and continues up to area seven. Other rooms have functions to support the industrial activities.

\section{CONCLUSION}

The financial analysis of a small-scale industrial production plant for cinnamon jelly candy resulted in a production capacity of $3,207 \mathrm{~kg}$ per year or equal to 64,128 packages, with a selling price of Rp. 9,300 per package. The investment value is Rp. 72,576,700 and a total annual cost of Rp. 564,741,395. The Net Present Value is Rp. 47,256,870, the Benefit-Cost Ratio is 1.11, the Internal Rate of Return is $32.80 \%$, the Pay Back Period is 2 years 3 months 21 days and the Break Event Point is 54.312 packages. Based on five years financial analysis, it is feasible to establish this small scale industry of cinnamon jelly candy. The layout design consists of 7 rooms and 5 areas in $156 \mathrm{~m} 2$ industrial building. It is adjusted to process activities and space requirements for tools and equipments. The total of industrial land area is 285 $\mathrm{m}^{2}$.

\section{ACKNOWLEDGMENT}

The team would like to express its sincerest gratitude to KemenristekDikti for providing the research funds and to the Department of Agro-Industrial Technology for providing the research facilities. Thanks to LPKT- ITI for the encouragement and constructive ideas. Appreciation goes to all colleagues, who not only helped but also gave suggestions, and all research assistants who made this research possible.

\section{REFERENCES}

[1] Angela Chrisellaa, A., N.Kusumawatia, T. I. P. Susenoa. "The influence different addition of Eucheumacotonii seaweed and gelatin with various concentration on physicochemical and organoleptic characteristic seaweed jelly candy". Journal of Food Technology and Nutrition Vol 14 (1): 38-45, 2015

[2] Habilla, C., S.Y.Sim, N. Aziah, and L.H. Cheng."The properties of jelly candy made of acid-thinned starch supplemented with konjac glucomannan or psyllium husk powder". International Food Research Journal 18: 213-220, 2011.

[3] Mahardika, Bani C., YS Darmanto, E. N.Dewi. "Karakteristik permen jelly dengan penggunaan campuran semi refined carrageenan dan alginat dengan konsentrasi berbeda". Jurnal Pengolahan dan Bioteknologi Hasil Perikanan Vol. 3 (3): 112-120, 2014.

[4] Bargal, H., M.Dashmishra, A. Sharma. "Performance analysis of small scale industries - a study of pre-liberalization and post-liberalization period". International Journal of Business and Management Vol. 1, No 2, 2009.
[5] Bank Indonesia. "Laporan inflasi (indeks harga konsumen) berdasarkan perhitungan inflasi tahunan".2018: https://www.bi.go.id/id/moneter/inflasi/data/ Default.aspx.

[6] Pratiwi, I, E. Muslimah dan A.Wahab Aqil."Perancangan tataletak fasilitas di industri tahu menggunakan blockplan". Jurnal Ilmiah Teknik Industri 11 (2),2012.

[7] Hartati, I., N. Widiasmadi, R. Subantoro. "Analisa kelayakan usaha produksi permen jelly kolangkaling di Limbangan Kendal”. Techno, Vol. 17( 1): 028 - 032 .

[8] Pratiwi, D., E. S. Djatikusuma. "Sweet rainbow (perencanaan pendirian usaha jelly candy)". Jurusan Manajemen STIE MDP, Palembang, unpublished.

[9] Tompkins W, Bozer and Tanchoco. Facilities planning. John Wiley \& Sons, Inc., 2010.

[10] Ojaghi, Y., A. Khademia, N. M. Yusofa, N. G. Renania, S. A. Helmi bin S. Hassan. "Production layout optimization for small and medium scale food industry". Procedia CIRP 26: $247-251,2015$.

[11] Mulugeta, A., B. Beshah and D.Kitaw. Computerized facilities layout design. Journal of EEA, Vol. 30, 2013. 